\title{
IMPLEMENTASI PENGUATAN PENDIDIKAN KARAKTER BERBASIS LINGKUNGAN MASYARAKAT PADA SEKOLAH DASAR
}

\author{
Muhammad Fauzan Muttaqin $^{1}$, Slamet Hariyadi ${ }^{2}$ \\ 1. Program Studi Pendidikan Guru Madrasah Ibtidaiyah, Fakultas Tarbiyah dan Keguruan, \\ Institut Daarul Qur'an, Indonesia \\ ${ }^{2}$ Guru SDN Candi 01, Semarang, Indonesia
}

Korespondensi. E-mail: muhammad.fauzan.muttaqin@gmail.com

\begin{abstract}
Abstrak
Penelitian ini bertujuan mengkaji secara spesifik tentang implementasi penguatan pendidikan karakter (PPK) berbasis masyarakat pada SD di Kota Semarang. Penelitian yang digunakan metode deskriptif pendekatan kualitatif dengan desain penelitian studi kasus. Pengumpulan data pada penelitian ini menggunakan metode checklist, observasi, wawancara semi terstruktur dan studi dokumentasi. Analisis data dilakukan dengan model analisis interaktif. Teknik keabsahan data yang digunakan adalah triangulasi teknik dan sumber. Hasil penelitian menunjukkan bahwa implemntasi PPK berbasis masyarakat melalui pemanfaatan sumber pembelajaran yang terdapat pada lingkungan sekitar dengan bekerjasama atau kolaborasi dengan masyarakat melalui kegiatan pembelajaran berbasis cagar budaya, musium, dan sanggar seni seperti Kota Lama Semarang, Masjid Agung Jawa Tengah, taman budaya Raden Saleh, Lawang Sewu, dan musium Ronggowasito, kerjasama dengan seniman dan budayawan sekitar dalam latihan ekstrakulikuler seni tari dan lukis; kelas inspirasi dengan mendatangkan narasumber tokoh profesional seperti dokter, tentara, polisi untuk mengisi kegiatan pembelajaran dalam ruang kelas dan di luar ruang kelas; gerakan literasi berkolaborasi dengan, PERPUSDA, percetakan, toko buku; kerjasama dengan PTN dan PTS meliputi riset pembelajaran, pengembangan inovasi pembelajaran, evaluasi menejemen sekolah; kerjasama sekolah dan komunitas keagamaan berupa rebana dan BTQ.
\end{abstract}

Kata Kunci: Implementasi, PPK berbasis masyarakat

\section{IMPLEMENTATION OF COMMUNITY-BASED CHARACTER EDUCATION RAINFORCEMENT IN ELEMENTARY SCHOOLS}

\begin{abstract}
The research goal examine specifically the implementation of community-based Character Education Rainforcement in elementary schools in the city of Semarang. This research uses descriptive qualitative approach with case study research design. Data collection methods used in this study were checklist, observation, semi-structured interviews and documentation studies. Data analysis was performed using an interactive analysis model. The data validity technique uses triangulation techniques and sources. The results showed that the implementation of community-based Character Education Rainforcement programs through the use of learning resources in the surrounding environment by working together or collaborating with the community through museum-based learning activities, cultural heritage, and art galleries such as Semarang Old City, Lawang Sewu, Great Mosque Central Java, the Raden Saleh cultural park, and Ronggowasito museum, mentoring with local artists and culturalists in dance and painting extracurricular exercises; inspiring classes by bringing in professional resource persons such as doctors, soldiers, police to fill class learning activities and outside the classroom; literacy movements in collaboration with, PERPUSDA, printing company, bookstores; collaboration with tertiary institutions including learning research, developing learning innovations, evaluating school management; school cooperation and religious communities such as rebana and BTQ.
\end{abstract}

Keywords: implementation, community-based Character Education Rainforcement

$$
\text { Copyright } @ 2020 \text {, JRPD, ISSN } 2615 \text { - } 1723 \text { (Print), ISSN } 2615 \text { - } 1766 \text { (Online) }
$$




\section{PENDAHULUAN}

Undang-Undang No. 20 Tahun 2003 menjelaskan tujuan potensi pengembangan karakter pada siswa. Peraturan Pemerintah No. 19 Tahun 2005 secara terdapat berbagai kompetensi yang berkaitan dengan karakter selain intelektualitas. Ini semua menjelaskan bahwa sebenarnya pendidikan bertugas mengembangkan karakter (Bavarian, 2016) dan intelektualitas pada kompetensi siswa.

Menurut Thomas Lickona terdapat tujuh nilai karakter yang perlu ditanamkan pada diri siswa diantarnya: ketulusan hati atau kejujuran, belas kasih, kegagahan beranian, kasih sayang, kontrol diri, kerjasama, dan kerja keras (Lickona, 2012:5). Pendidikan karakter berkaitan erat dengan teori belajar Behavioristik dikaranakan tujuan dari pendidikan karakter sama dengan teori ini yaitu menginginkan adanya perubahan tingkah laku siswa yang tadinya belum baik menjadi lebih baik.

Upaya mencapai hal tersebut, pemerintah menetapkan Peraturan Presiden Pasal 18 No. 87 Tahun 2017 yang menjelaskan pada penyelenggaraan PPK pada tingkat satuan pendidikan formal dilakukan secara terintegrasi. Pengintegrasian tersebut meliputi keterpaduan kegiatan dalam kelas, luar kelas, dan dalam masyarakat. Implementasi pengintegrasian PPK berbasis masyarakat pada sekolah membutuhkan kerjasama dengan beberapa lembaga, komunitas, organisasi dan masyarakat di sekitar sekolah. Pengintegrasian tersebut bertujuan untuk membangun jejaring pelibatan masyarakat (publik) sebagai sumbersumber belajar di dalam dan di luar sekolah sehingga dapat memperdalam dan memperluas pengembangan karakter pada siswa.

Namun, pada realitanya penerapan program pendidikan karakter perlu perbaikan (Ariyani, 2017) karena belum maksimalnya pendidikan karakter disebabkan oleh guru yang hanya memperhatikan aspek kognitif, dan mengabaikan aspek afektif, psikomotor, dan spiritual peserta didik (Prihastanto, 2016).
Hasil observasi awal juga menjelaskan beberapa sekolah belum mengagendakan program kerjasama khusus dengan masyarakat sekitar dalam penerapan karakter pada siswa. Selain itu pengawasan dan pelaksanaan pendidikan karakter oleh keluarga dalam perkembangannya karakter anak masih kurang berkembang secara optimal ditunjukkan dengan perilaku anak keras kepala, egois dan tindak memiliki tanggung jawab sosial (Ekosiswoyo dkk., 2016).

Berdasarkan penjelasan tersebut, maka diperlukan penelitian yang bertujuan mengkaji secara spesifik tentang implementasi PPK berbasis masyarakat pada SD di Kota Semarang. Selain itu, PPK merupakan program terbaru dari pemerintah dalam mewujudkan revolusi karakter bangsa seperti yang ada dalam Nawacita 8 dan membentuk karakter generasi emas pada 2045 mendatang (Manullang, 2013)

\section{METODE}

Penelitian yang digunakan metode deskriptif dengan pendekatan kualitatif dengan desain penelitian studi kasus yang bertujuan untuk mengungkap secara komprehensif implementasi PPK berbasis lingkungan masyarakat pada SD. Sumber data dalam penelitian ini dipilih secara purposive sampling yakni sekolah pilot project PPK di Kecamatan Candisari dari keseluruhan SD di Kota Semarang yang sudah menerapkan PPK, di antaranya: SDN Candi 01, SDN Kaliwiru, SDN Karanganyar Gunung 01 dan SDN Wonotingal. Pengumpulan data pada penelitian ini menggunakan checklist, observasi, wawancara semi terstruktur dan dokumentasi. Pengujian data mengunakan trianggulasi teknik dan sumber. Teknik analisisnya menggunakan Metode Analisis data kualitatif model Milles and Huberman (Iskandar, 2013:233).

\section{Copyright (C2020, JRPD, ISSN 2615 - 1723 (Print), ISSN 2615 - 1766 (Online)}




\section{HASIL DAN PEMBAHASAN}

Implementasi PPK berbasis masyarakat diterapkan melalui kegitan kolaborasi dengan lembaga, komunitas, dan masyarakat lain dilingkungan sekitar sekolah. Partisipasi masyarakat sangat dibutuhkan karena sekolah dalam melaksanakan PPK tidak bisa secara mandiri. Karena itu, sekolah membentuk kolaborasi dan kerjasama dengan beberapa komunitas diluar sekolah dalam menerapkan penguatan pendidikan karakter. Berdasarkan hasil observasi sesuai pedoman penilaian PPK KEMENDIKBUD terhadap tingkat keberhasilan implementasi berbasis masyarakat melalui dukungan dari masyarakat dan peran komite sekolah untuk PPK di sekolah dasar telah baik dengan persentase $82,5 \%$ - 90\%. Penerapan pelibatan masyarakat sudah terlakna dengan baik bahkan ada satu sekolah sudah menerapkan dengan sangat baik dengan presentase $82,5 \%$ - 92,5\%. Pemanfaatan sember-sumber pembelajaran di luar lingkuan sekolah dan suber-sumber pendanaan masyarakat sudah berjalan dengan baik dengan presentase $80 \%$ - 90\%. Namun, sekolah yang belum maksimal menerapkan evaluasi dan perbaikan PPK dengan persentase $77,5 \%$ - 82,5\%. Akibatnya, sekolah dasar belum maksimal dalam penerapan PPK berbasis masyarakat. Lebih lengkapnya bisa dilihat pada Gambar 1.

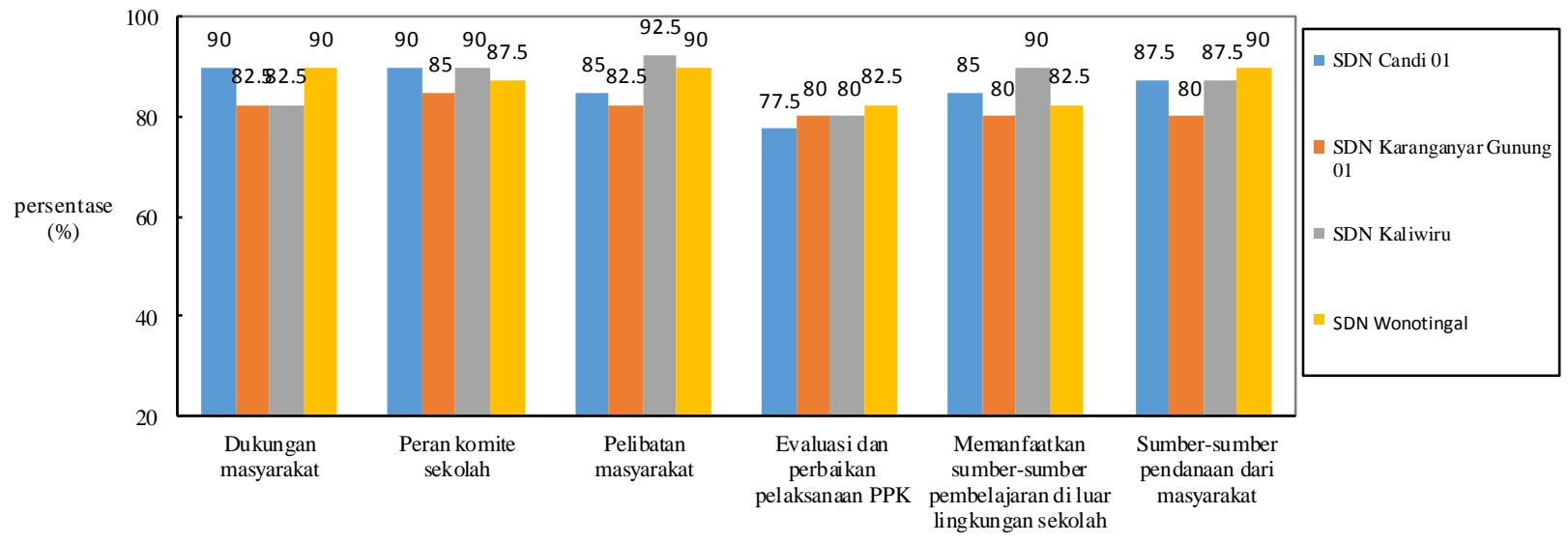

Indikator Implementasi PPK Berbasis Budaya Masyrakat

Gambar 1. Diagram kualitas keberhasilan implementasi PPK berbasis budaya masyarakat

Penerapan PPK berbasis masyarakat dalam bentuk kolaborasi sekolah dengan lingkungan mayarakat telah dilakukan oleh sekolah melalui beberapa kegiatan diantaranya:

1. Pembelajaran Berbasis Musium, Cagar

Budaya, dan Sanggar Seni.

Sekolah dalam melaksanakan PPK berbasis masyarakat dapat memanfaatkan sumber-sumber pembelajaran terdapat di lingkungan sekitar mereka. Beberapa daerah memiliki musium yang dapat digunakan sebagai sarana dan sumber pembelajaran untuk siswa, sekolah bisa berkolaborasi dengan pengelola musium, cagar budaya, yang bertujuan untuk memperkenalkan dan menjelaskan koleksi sejarahnya, mengajak siswa untuk mempelajari kekayaan daerahnya, dan mampu menjaga kekayaan warisan budaya yang mereka miliki. sekolah juga bisa berkolaborasi dengan kelompok hobi, komunitas budaya, dan sanggar dalam 
memperdalam ilmu dan mempraktekan warisan budaya yang ada. Sekolah telah mengadakan pembelajaran luar sekolah yang bekerjasaa dengan orang tua siswa ke Kota Lama Semarang, Masjid Agung Jawa Tengah, taman budaya Raden Saleh, Lawang Sewu, dan musium Ronggowasito.

Penerapan pembelajaran luar sekolah juga sudah di rencanakan oleh kepala SD N Wonotingal dan kepala SD N Kaliwiru ke tempat-tempat edukasi di daerah Kota Semarang. Pembelajaran luar sekolah yang sudah dilakukan oleh guru kegiatan di musium Ronggowasito Semarang tentang sejarah dan Taman budaya Raden Saleh untuk pemahaman budaya bangsa sekaligus belajar melukis sebagai bentuk pelestarian budaya. Siswa juga menjelaskan bahwa sekolah pernah mengadakan pembelajaran luar sekolah ke Taman budaya Raden Saleh, musium Rongggowasito, sholat di Masjid Agung Jawa Tengah dan Lawang Sewu. Tujuan diadakanya pembelajaran di musium untuk hiburan dan edukasi (Yudiantika dkk, 2013) siswa. Selain itu, pembelajaran ke cagar budaya membawa siswa mengetahui warisan budaya daerah yang ada. Namun, beberapa sekolah belum melakukan kegiatan kunjungan warisan budaya dengan baik dalam pendidikan di SD (Hằng $\mathrm{dkk}, 2015)$ karena keterbatasan biaya dan waktu.

2. Mentoring dengan Seniman dan Budayawan Lokal.

Sekolah membangun kolaborasi dan kerjasama untuk pengembangan kesenimanan siswa melalui tokoh-tokoh budayawan atau seniman lokal dalam program mentoring, tutoring, ekstrakulikuler kesenian di sekolah. Kerjasama sekolah dengan seniman yang sudah terjalin melalui kegiatan latihan ekstrakulikuler seni tari di sekolah. Kerjasama sekolah dengan seniman yang sudah terjalin melalui kegiatan mentoring kesenian tari dan tutoring melukis.

Kerjasama sekolah dengan seniman yang guru pahami melalui kegiatan mengajar ektraklikuler seni tari. Siswa juga menjelaskan yang mengajar tari adalah seniman dari luar sekolah. Sekolah yang sudah bekerjasama dengan tokoh budayawan dan seniman sekitar yang baik sehingga mampu membentuk tradisi dan kesenian khusus sekolah dalam mengembangkan kesenian siswa melalui program mentoring, tutoring, seniman masuk ke sekolah, atau belajar bersama maestro.

Bentuk kolaborasi sekolah dengan seniman yang sudah terjalin melalui kegiatan latihan ekstrakulikuler seni tari dan lukis di sekolah. Bentuk kerjasama lainnya dengan seniman melalui kegiatan mentoring dan tutoring melukis saat persiapan mengikuti lomba budaya. Pada kegiatan ekstrakulikuler proses pembelajaran tari menggunakan metode latihan (Novantie dkk, 2017), jadi langsung pratek bersama pelatih. Pembelajaran seni tari berpengaruh secara efektif pada peningkatan kecerdasan kinestetik (Yetti \& Juniasih, 2016) siswa. Kegiatan tutoring melukis dilakukan setiap akan ada perlombaan melukis.

3. Kelas Inspirasi.

Kelas inspirasi memiliki tujuan suapaya siswa memdapatkan inspirasi dari pengalaman hidup tokoh-tokoh profesional yang sudah berhasil didatangkan sehingga dapat berefek positif pada semangat dan motivasi siswa dalam meningkatkan prestasi belajar mereka. Metode yang bisa dilakukan untuk menerapkan kelas inspirasi melalui kegiatan pendahuluan; kegiatan inti meliputi: metode ice breaker, curah pendapat, game, diskusi, presentasi, debat, musyawarah, one on one, bimbingan kelompok, alih teks, pemutaran film, role play, serta karya wisata; kegiatan penutup (Utami, 2017).

Setiap guru dapat menerapkan kelas inspirasi untuk siswa melalui kerjasama dengan individu yang memiliki profesi sangat beragam untuk hadir dalam ruang kelas. Sekolah bisa mendatangkan narasumber dari wali murid atau tokoh masyarakat sekitar untuk menjadi narasumber materi pembelajaran untuk dapat menginspirasi pembentukan nilai-nilai karakter serta penguatan karakter pada diri siswa. Tujuan lain dari kelas inspirasi dapat membantu setiap Copyright @2020, JRPD, ISSN 2615 - 1723 (Print), ISSN 2615 - 1766 (Online) 
siswa memperluas wawasan dan inspirasi tentang cita-cita, memberikan motivasi untuk terus melanjutkan pendidikan, menanamkan nilai kejujuran, kerja keras, dan mandiri serta menghormati orang tua. Pelaksanaan kelas inspirasi memiliki interaksi kolaborasi dan sikap dasar kelas inspirasi di sekolah dasar yang Lebih lengkapnya bisa dilihat pada Gambar 2.
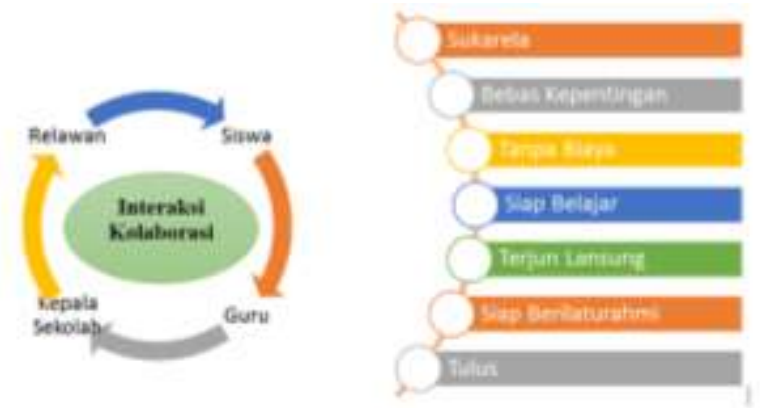

Gambar 2. Interaksi kolaborasi dan sikap dasar kelas inspirasi.

Implementasi kelas inspirasi yang sudah dilakukan sekolah dengan mengundang orang tua siswa sebagai narasumber tokoh-tokoh profesional dalam bidangnya dokter, tentara, polisi untuk mengisi kegiatan pembelajaran dalam ruang kelas dan di luar ruang kelas seperti pada kegiatan upacara. Sekolah dapat mengundang narasumber atau tokoh inspirator dari orang tua siswa atau tokoh-tokoh yang ada di masyarakat sekitar. Penerapan kelas ispirasi yang sudah dilakukan oleh guru mendatangkan narasumber dokter dan seniman untuk mengisi saat proses pembelajaran. Kegiatan kelas inspirasi dengan narasumber dokter membuat siswa memahami kebersihan dan kesehatan. Selain dokter guru juga mendatangkan narasumber seniman yang membuat siswa tentang kerampilan melukis. Pelaksanaan kelas inspirasi kedepannya membawa hubungan baik antara sekolah dengan orang tua siswa dan masyarakat untuk kepentingan pembangunan karakter siswa di sekolah.

4. Gerakan Literasi.

Pelaksanaan literasi di sekolah bertuju kepada materi nilai-nilai budi pekerti yang diambil berlandaskan kearifan budaya lokal akan tetapi masih disesuaikan dengan karakteristik berkembangnya siswa (Oktaviani dkk, 2017). Freeman (2014) menjelaskan dalam kegiatan literasi berbasis pendidikan karakter membantu anak usia 4 sampai 6 tahun memiliki pemahaman tentang pencegahan intimidasi. Pengembangan gerakan literasi di sekolah membangun kerjasama dengan instansi-instansi yang berkaitan dengan literasi diantaranya: komunitas gerakan masyarakat peduli literasi pendidikan, komunitas baca atau sanggarsanggar baca, percetakan buku, penerbit buku, toko buku, perpustakaan daerah, dan perpustakaan nasional. Kolaborasi yang dilakukan SDN Wonotingal dengan perpustakaan daerah dan percetakan melalui pengadaan buku. Sekolah lainnya belum berkolabolasai dan ada yang baru merencanakan kerjasama dengan instansi pemerintah daerah.

5. Kolaborasi dengan Perguruan Tinggi: Riset Dosen-Guru.

Sekolah membenuk kerjasama dengan PTN dan PTS bertujuan untuk meningkatkan kualitas proses pembelajaran guru-guru. Selain itu, PTN dan PTS dapat memanfaatkan pengalaman sekolah untuk laboratorium dalam mengembangkan beberapa teori pembelajaran dalam pendidikan, yang berefek pada peningkatan keterampilan dan kompetensi guru. Sekolah telah melakukan kolaborasi dengan beberapa perguruan tinggi negeri dan swasta sebagai laboraturium pembelajaran mahasiswa untuk skripsi dan tesis.

Kepala sekolah bersikap terbuka untuk dosen dan mahasiswa yang akan melakukan kegiatan penelitian di sekolahnya. Kolaborasi yang telah dilakukan melalui kegiatan pengembangan pembelajaran dan evaluasi manejemen sekolah. Adanya kolaborasi mahasiswa dengan guru dalam pengembangan model pembelajaran dan pengembangan inovasi pebelajaran. 
Sekolah telah berkolaborasi dengan PTN dan PTS di daerah Semarang sebagai laboraturium pembelajaran mahasiswa untuk kegiatan pengembangan model pembelajaran, pengembangan inovasi pebelajaran, evaluasi manejemen sekolah. Selain itu, model pendampingan PTK, kolaborasi ini menempatkan mahasiswa sebagai pembelajar, magang, yang berinteraksi langsung dengan permasalahan sekolah dan memperoleh pengalaman langsung tindakan pedagogi yang dilakukan guru (Zulfiani dkk, 2016) pada saat pembelajaran di dalam kelas maupun lingkungan sekolah.

6. Kerjasama dengan Komunitas Keagamaan.

Kerjasama atau kolaborasi dengan komunitas keagamaan dapat diterapkan melalui kerjasama antar lembaga yang memfasilitasi layanan khusus untuk pendalaman keagamaan, sesuai menurut agama kepercayaan masing-masing siswa. Bentuk kolaborasi dengan komunitas keagamaan melalui mentoring kegiatan ekstrakulikuler rebana dan BTQ di sekolah. Sekolah berkerjasama dengan komunitas karena guru agama masih belum memenuhi untuk kegiatan religius di sekolah. Kerjasama dengan komunitas Islam dan komunitas Kristen dapat meningkatkan ikatan solidaritas dalam masyarakat (Purnamasari, 2017).

\section{Kendala Penguatan Pendidikan Karakter Berbasis Masyarakat}

Implemntasi PPK berbasis masyarakat pada pelaksaannya terdapat kendala-kendala yang dihadapi oleh sekolah diantaranya: terbatasnya anggaran sekolah untuk mengadakan pembelajaran di luar ruang kelas dan membiayai pelatih seni tari dan rebana, terbatasnya alat kesenian, terbatasnya inforasi narasumber kelas inspirasi, penyempurnaan administrasi perpustakaan sekolah, jadwal kegiatan kolaborasi dengan PTN dan PTS yang bersamaan kegiatan penting sekolah dan minimnya feedbacknya ke sekolah.

\section{SIMPULAN}

Implementasi PPK berbasis masyarakat melalui pemanfaatan implemntasi PPK berbasis masyarakat melalui pemanfaatan sumber pembelajaran yang terdapat pada lingkungan sekitar dengan bekerjasama atau kolaborasi dengan masyarakat melalui kegiatan pembelajaran berbasis cagar budaya, musium, dan sanggar seni seperti Kota Lama Semarang, Masjid Agung Jawa Tengah, taman budaya Raden Saleh, Lawang Sewu, dan musium Ronggowasito, kerjasama dengan seniman dan budayawan sekitar dalam latihan ekstrakulikuler seni tari dan lukis; kelas inspirasi dengan mendatangkan narasumber tokoh profesional seperti dokter, tentara, polisi untuk mengisi kegiatan pembelajaran dalam ruang kelas dan di luar ruang kelas; gerakan literasi berkolaborasi dengan, PERPUSDA, percetakan, toko buku; kerjasama dengan PTN dan PTS meliputi riset pembelajaran, pengembangan inovasi pembelajaran, evaluasi menejemen sekolah; kerjasama sekolah dan komunitas keagamaan berupa rebana dan BTQ.

Penelitian selanjutnya diharapkan mampu menfokuskan pada salah satu jenis kolaborasi dala menerapkan PPK berbasis masyarakat sehingga data yang didapatkan lebih detail.

\section{DAFTAR PUSTAKA}

Ariyani, E. (2017). "Evaluation Of Implementation Character Education Program At Senior High School In Mataram City". JERAM, 1(1): 15-24

Bavarian, N., Lewis, K. M., Acock, A., DuBois, D. L., Yan, Z., Vuchinich, S., ... \& Flay, B. R. (2016). "Effects of a school-based social-emotional and character development program on health behaviors: A matched-pair, cluster-randomized controlled trial". The journal of primary prevention, 37(1): 87-105. 
Ekosiswoyo, R., Joko, T., \& Suminar, T. (2016). "Potensi Keluarga Dalam Pendidikan Holistik Berbasis Karakter Pada Anak Usia Dini”. Edukasi, 1(1):1-19.

Hằng, N. V. T., Meijer, M. R., Bulte, A. M., \& Pilot, A. (2015). "The implementation of a social constructivist approach in primary science education in Confucian heritage culture: the case of Vietnam". Cultural Studies of Science Education, 10(3): 665-693.

Iskandar. (2013). Metode Penelitian Pendidikan dan Sosial. Jakarta: Referensi.

Likcona, T. (2012). Character Matters. Terjemahan. Juma Wudu Wamaunggu \& Jean Antunes Rudolf Zin dan Editor. Uyu Wahyudin \& Suryani. Jakarta: bumi aksara.

Manullang, B. (2013). "Grand Desain Pendidikan Karakter Generasi Emas 2045". Jurnal Pendidikan Karakter, (1):1-14.

Novantie, R. A., Handayani, E. W., \& Si, M. (2017). "Tari Jaran Ngincik Dalam Pembelajaran Ekstrakurikuler Tari Di Sdn Mangkujajar Kembangbahu Lamongan". Jurnal Pendidikan Sendratasik, 5(1):-17.

Oktaviani, I., Zuliana, E., \& Ratnasari, Y. (2017). "Menggagas Kajian Kearifan Budaya Lokal di Sekolah Dasar Melalui Gerakan Literasi Sekolah. Aktualisasi Kurikulum 2013 dIi Sekolah Dasar Melalui Gerakan Literasi Sekolah untuk Menyiapkan Generasi Unggul dan Berbudi Pekerti”. Prosiding Seminar Nasional 15 Maret 2015 hal: 35-42.

Purnamasari, D. E. (2017). Solidaritas Mekanik Komunitas Islam Dan Kristen Di Desa Kamijoro Kecamatan Bener Kabupaten Purworejo. In Forum Ilmu Sosial, 42(2): 161-176.

Utami, E. (2017). Generasi Emas 2045: Indonesia Membutuhkan Kelas Inspirasi dan Pendidik Super Kreatif.
Prosiding FKIP Universitas Ahmad Dahlan.

Prihastanto, A., Samsudi, S., Masrukhi, M., \& Prihatin, T. (2016). "The Development Of Holistic Model Of Character Education Management For Senior High Schools In Pemalang Regency". The Journal of Educational Development, 4(1): 73-82

Yetti, E., \& Juniasih, I. (2016). "Implementasi Model Pembelajaran Tari Pendidikan Untuk Meningkatkan Kecerdasan Kinestetik Anak Usia Dini Melalui Metode Pembelajaran Aktif (Pengembangan Model Di Taman Kanak-kanak Labschool Jakarta Pada Kelompok B)". JPUD-Jurnal Pendidikan Usia Dini, 10(2): 385-400.

Yudiantika, A. R., Pasinggi, E. S., Sari, I. P., \& Hantono, B. S. (2013). Implementasi Augmented Reality Di Museum: Studi Awal Perancangan Aplikasi Edukasi Untuk Pengunjung Museum. Yogyakarta: Konferensi Nasional Teknologi Informasi dan Komunikasi (KNASTIK), Fakultas Teknologi Informasi, Universitas Kristen Duta Wacana.

Zulfiani, Z., Herlanti, Y., \& Sofyan, A. (2016). "Kajian Penerapan Pendampingan Penelitian Tindakan Kelas Kolaboratif Antara Perguruan Tinggi Dan Sekolah". Cakrawala Pendidikan, 35(2): 273-283. 